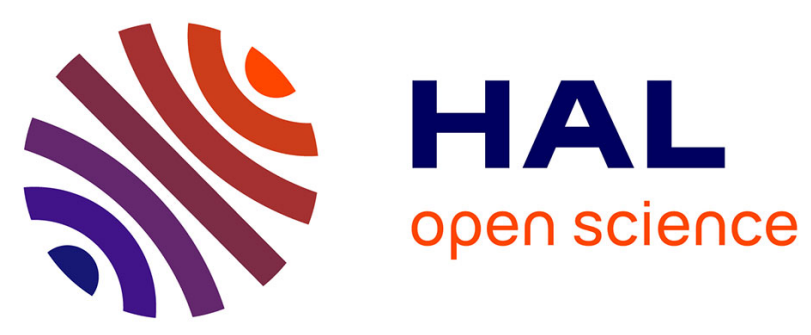

\title{
Nitrogen evolution as anodic reaction in molten LiF-CaF2
}

Laurent Massot, Pierre Chamelot, Mathieu Gibilaro, Laurent Cassayre, Pierre Taxil

\section{- To cite this version:}

Laurent Massot, Pierre Chamelot, Mathieu Gibilaro, Laurent Cassayre, Pierre Taxil. Nitrogen evolution as anodic reaction in molten LiF-CaF2. Electrochimica Acta, 2011, vol. 56, pp. 4949-4952. 10.1016/j.electacta.2011.03.131 . hal-00813228

\section{HAL Id: hal-00813228 https://hal.science/hal-00813228}

Submitted on 15 Apr 2013

HAL is a multi-disciplinary open access archive for the deposit and dissemination of scientific research documents, whether they are published or not. The documents may come from teaching and research institutions in France or abroad, or from public or private research centers.
L'archive ouverte pluridisciplinaire HAL, est destinée au dépôt et à la diffusion de documents scientifiques de niveau recherche, publiés ou non, émanant des établissements d'enseignement et de recherche français ou étrangers, des laboratoires publics ou privés. 


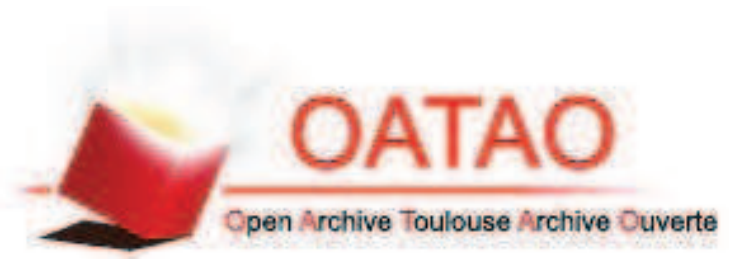

\section{Open Archive Toulouse Archive Ouverte (OATAO)}

OATAO is an open access repository that collects the work of Toulouse researchers and makes it freely available over the web where possible.

This is an author-deposited version published in: http://oatao.univ-toulouse.fr/ Eprints ID: 8611

To link to this article: DOI: 10.1016/j.electacta.2011.03.131

URL : http://dx.doi.org/10.1016/j.electacta.2011.03.131

\section{To cite this version:}

Massot, Laurent and Chamelot, Pierre and Gibilaro, Mathieu and Cassayre, Laurent and Taxil, Pierre Nitrogen evolution as anodic reaction in molten LiFCaF2. (2011) Electrochimica Acta, vol. 56 (n 14). pp. 4949-4952. ISSN 00134686 


\title{
Nitrogen evolution as anodic reaction in molten $\mathrm{LiF}-\mathrm{CaF}_{2}$
}

\author{
L. Massot*, P. Chamelot, M. Gibilaro, L. Cassayre, P. Taxil \\ Université de Toulouse, INPT, UPS, CNRS, Laboratoire de Génie Chimique, Département Procédés Electrochimiques, F-31062 Toulouse Cedex 9, France
}

\begin{abstract}
A B S T R A C T
The electrochemical behaviour of nitride ions has been studied in fluoride melts (eutectic $\mathrm{LiF}_{-} \mathrm{CaF}_{2}$ ) by cyclic voltammetry and square wave voltammetry. The purpose of this work is to propose an alternative way for anodic reaction in molten fluorides processes. Thermodynamical analysis can be used for the evaluation of the anodic material regarding to its oxidation potential and reactivity with nitrogen. Then electrochemical investigations confirm the oxidation of nitride ions into nitrogen in a one-step process exchanging 3 electrons, and let propose several materials usable for nitrogen evolving.
\end{abstract}

Keywords:

Molten fluorides

Anodic reaction

Nitrogen evolution

Thermodynamics

Electrochemical pathway

\section{Introduction}

One of the main limitations in high temperature electrochemical reduction processes in molten halide salts is the anodic reaction. In the case of molten chlorides, the anodic reaction can be the oxidation of chloride ions into chlorine; although in molten fluorides, the oxidation of fluoride ions into fluorine cannot occur without oxidation of the anodic material. Concerning media containing oxide, the two possibilities are the production of carbon dioxide on carbon, as in the Hall-Héroult electrodeposition process of aluminium, or oxygen on inert anodes [1,2], respectively. But for free oxide media, as metal electrodeposition processes (except aluminium), the anodic reaction represents a real problem. An alternative anodic reaction has been investigated: the production of nitrogen by oxidation of nitride ions $\left(\mathrm{N}^{3-}\right)$.

This kind of anodic reaction has been proposed in the particular case of nuclear applications, with the proposal of a new nitride nuclear fuel cycle based on molten salts [3]. The main process of the proposed fuel recycling consists in the anodic dissolution of spent nitrides with nitrogen evolution, and the cathodic electro refining in molten chloride salts.

However, the importance of molten fluorides for pyrochemical reprocessing becomes higher due to their electrochemical properties, high chemical stability and high elements solubility. Consequently, the electrochemical behaviour of nitride ions in molten fluorides has to be studied and the possibility of nitrogen

\footnotetext{
* Corresponding author. Tel.: +33 561558194; fax: +33 561556139.

E-mail address: massot@chimie.ups-tlse.fr (L. Massot).
}

evolution as anodic reaction must be verified in order to validate this process in molten fluorides.

All the previous studies concerning the electrochemical behaviour of nitrides, presented in the bibliography, have been performed in molten chlorides. Ito et al. examined the $\mathrm{N}_{2(\mathrm{~g})} / \mathrm{N}^{3-}$ electrochemical system in molten $\mathrm{LiCl}-\mathrm{KCl}$ at $723 \mathrm{~K}$ [4]. The electrochemical reduction of nitrogen into nitride ions on a nickel cathode was investigated and the reaction standard potential experimentally determined. Then a quantitative oxidation of nitride ions into nitrogen on a nickel anode has been demonstrated. Other works in the same laboratory concerned the preparation of some metal nitrides by reactive oxidation in molten $\mathrm{LiCl}-\mathrm{KCl}$, such as aluminium nitride AlN [5], zirconium nitride $\mathrm{ZrN} \mathrm{[6]} \mathrm{and} \mathrm{tin} \mathrm{nitride}$ $\mathrm{SnN}_{\mathrm{X}}$ [7] studied by Goto et al., and iron nitride $\mathrm{Fe}_{2} \mathrm{~N}$ studied by Tsujimura et al. [8].

The first part of this work is a thermodynamic evaluation of the anodic material reactivity regarding to nitride ions. Then, an experimental verification has been performed in order to select the appropriate anodic material. Two different behaviours are expected: (i) either the anodic material reacts with nitride ions to form metallic nitrides or (ii) the anodic material is inert regarding to nitrides and could be used as anode for nitrogen evolution. The behaviour of several anodic materials (W, $\mathrm{Cu}, \mathrm{Ag}$, Pt and $\mathrm{Au}$ ) has been examined and the electrochemical mechanism of nitride ions oxidation has been detailed.

\section{Experimental}

The cell was composed of a vitreous carbon crucible placed in a cylindrical vessel made of refractory steel and closed by a stainless 


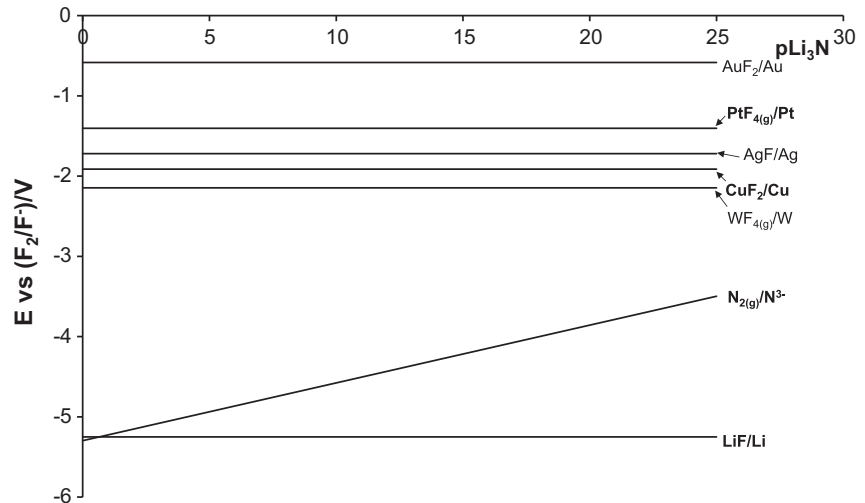

Fig. 1. E-pLi ${ }_{3} \mathrm{~N}$ diagram of electrode materials (W, Cu, Ag, Pt and $\mathrm{Au}$ ) at $1113 \mathrm{~K}$.

steel lid cooled by circulating water. A more detailed description is given in previous paper [9].

The electrolytic bath consisted of a eutectic LiF-CaF 2 (Merck $99.99 \%$ ) mixture (79/21 mol\%). Nitride ions were introduced into the bath in the form of powder of lithium nitride, $\mathrm{Li}_{3} \mathrm{~N}$ (Merck 99.99\%).

Electrodes: gold, platinum (0.5 mm diameter), copper, tungsten and silver ( $1 \mathrm{~mm}$ diameter) were used as working electrodes. The auxiliary electrode was a vitreous carbon (V25) rod with a large surface area $\left(2.5 \mathrm{~cm}^{2}\right)$. The potentials were referred to a platinum wire $(0.5 \mathrm{~mm}$ diameter $)$ acting as a quasi-reference electrode $\mathrm{Pt} / \mathrm{PtO}_{x} / \mathrm{O}^{2-}[10]$.

Electrochemical techniques: cyclic voltammetry and squarewave voltammetry were used for the investigation of the $\mathrm{Li}_{3} \mathrm{~N}$ oxidation process, and were performed with an Autolab PGSTAT30 controlled by a computer using the research software GPES 4.9.

\section{Results and discussion}

\subsection{Thermodynamic analysis}

A preliminary thermodynamic discussion is necessary in order to select the anodic material. Two electrochemical behaviours are possible: (i) nitride ions are directly oxidized into nitrogen at the inert anode surface, and (ii) the anodic material is oxidized into metal nitride.

Concerning nitrogen evolving, according to the Nerns't Law, only materials having their oxidation potential higher than nitrogen evolving reaction one could be used. Moreover, the anodic metal must be inert regarding to nitrides ions. This could be verified by analyzing the Metal-Nitrogen binary alloy phase diagram.

As nitride ions were introduced in the form of $\mathrm{Li}_{3} \mathrm{~N}$, which is assumed to be completely dissociated, the $\mathrm{N}^{3-}$ activity in the solution used for thermodynamic calculations can be expressed by $p_{L_{3} \mathrm{~N}}=-\log \left(a_{\mathrm{Li}_{3} \mathrm{~N}}\right)$. The stability zones of all the species possibly involved in the electrochemical oxidation process as a function of the $\mathrm{N}^{3-}$ activity in the bath can be evidenced in a E- $\mathrm{p}_{\mathrm{Li3N}}$ diagram. The $\mathrm{N}_{2(\mathrm{~g})} / \mathrm{N}^{3-}$ standard potential was calculated using the free enthalpy of the $\mathrm{N}_{2(\mathrm{~g})}$ formation reaction $\left(\mathrm{Li}_{3} \mathrm{~N}+3 / 2 \mathrm{~F}_{2(\mathrm{~g})}=1 / 2 \mathrm{~N}_{2(\mathrm{~g})}+3 \mathrm{LiF}\right)$ which has been determined using thermodynamic database. This diagram was plotted for several electrode materials ( $\mathrm{W}, \mathrm{Cu}, \mathrm{Ag}, \mathrm{Pt}$ and $\mathrm{Au}$ ), in Fig. 1, using HSC 6.1 software at $1113 \mathrm{~K}$, with all soluble species activities equal to $0.1 \mathrm{~mol} \mathrm{~kg}^{-1}$.

It can be observed on this figure that all the materials examined have an oxidation potential higher than nitrogen evolution whatever the nitride ions content. Thus, these materials are considered as inert regarding to nitrides.

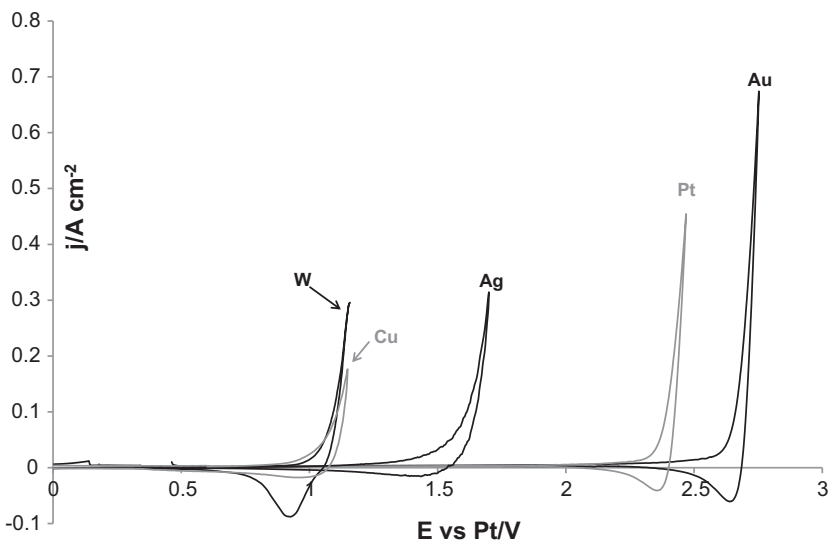

Fig. 2. Comparison of cyclic voltammograms in $\mathrm{LiF}_{-} \mathrm{CaF}_{2}$ on several electrode materials at $1113 \mathrm{~K}$ and $100 \mathrm{mV} \mathrm{s}^{-1}$. Aux el: vitreous carbon, Ref el: Pt.

The following part of the study is dedicated to the experimental verification of the thermodynamic assumptions using electrochemical techniques.

\subsection{Electrochemical behaviour of nitride ions}

\subsubsection{Selection of anodic electrode material}

The first experiments were conducted in order to validate the thermodynamic analysis by performing cyclic voltammetry in the $\mathrm{LiF}-\mathrm{CaF}_{2}$ system at $1113 \mathrm{~K}$ at $100 \mathrm{mV} \mathrm{s}^{-1}$, on each electrode material, as presented in Fig. 2. This figure highlights the oxidation potential of the different electrodes with the associated reactions:

$$
\begin{aligned}
& \mathrm{W}+4 \mathrm{~F}^{-}=\mathrm{WF}_{4(\mathrm{~g})}+4 \mathrm{e}^{-} \quad(E=1.07 \mathrm{VvsPt}) \\
& \mathrm{Cu}+2 \mathrm{~F}^{-}=\mathrm{CuF}_{2}+2 \mathrm{e}^{-} \quad(E=1.09 \mathrm{VvsPt}) \\
& \mathrm{Ag}+\mathrm{F}^{-}=\mathrm{AgF}+\mathrm{e}^{-} \quad(E=1.58 \mathrm{VvsPt}) \\
& \mathrm{Pt}+4 \mathrm{~F}^{-}=\mathrm{PtF}_{4(\mathrm{~g})}+4 \mathrm{e}^{-} \quad(E=2.40 \mathrm{VvsPt}) \\
& \mathrm{Au}+2 \mathrm{~F}^{-}=\mathrm{AuF}_{2}+2 \mathrm{e}^{-} \quad(E=2.74 \mathrm{VvsPt})
\end{aligned}
$$

This result is in good agreement with thermodynamic assessment.

If nitride ions oxidation potential is lower than the one of these metals, they could be considered as inert regarding to nitrogen production.

Thus, the same comparison has been performed on each material after addition of $\mathrm{Li}_{3} \mathrm{~N}\left(0.105 \mathrm{~mol} \mathrm{~kg}^{-1}\right)$ at $1113 \mathrm{~K}$, as presented in Fig. 3. On this figure, a new anodic wave beginning at around $1 \mathrm{~V} v \mathrm{vs}$

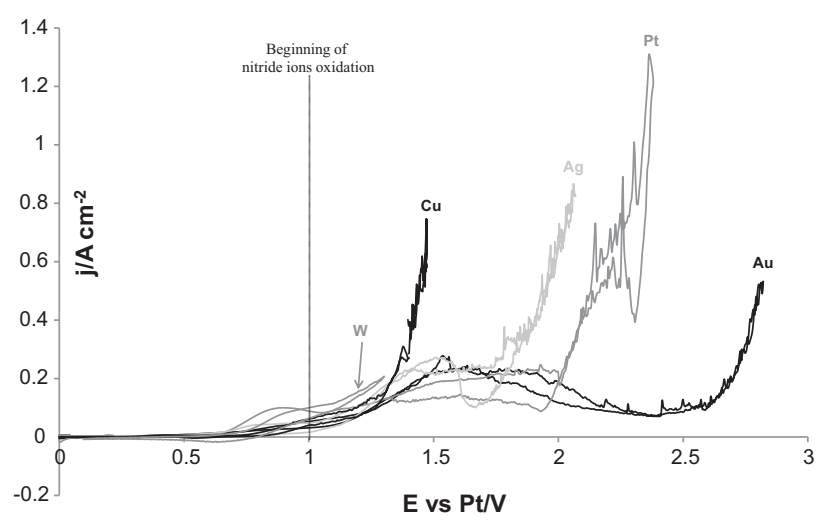

Fig. 3. Comparison of cyclic voltammograms in $\mathrm{LiF}_{-} \mathrm{CaF}_{2}-\mathrm{Li}_{3} \mathrm{~N}\left(0.105 \mathrm{~mol} \mathrm{~kg}^{-1}\right)$ on several electrode materials at $1113 \mathrm{~K}$ and $100 \mathrm{mV} \mathrm{s}^{-1}$. Aux el: vitreous carbon, Ref el: Pt. 


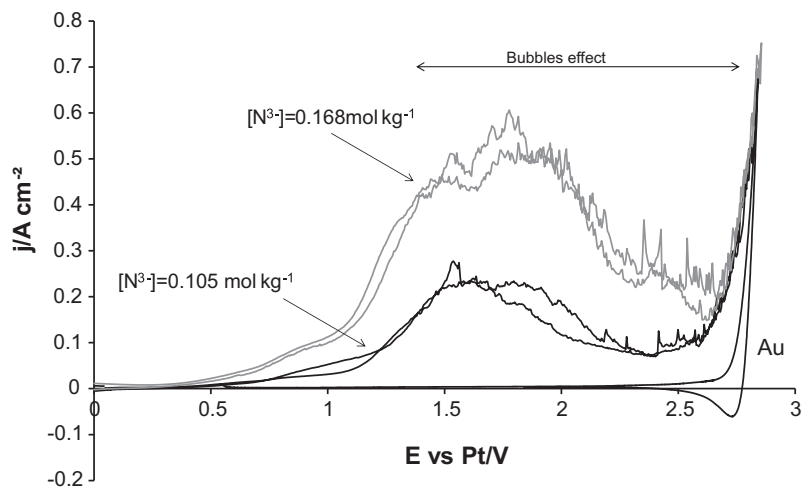

Fig. 4. Cyclic voltammograms of $\mathrm{LiF}-\mathrm{CaF}_{2}-\mathrm{Li}_{3} \mathrm{~N}$ on $\mathrm{Au}$ electrode at $1113 \mathrm{~K}$ and $100 \mathrm{mV} \mathrm{s}^{-1}$ for different $\mathrm{Li}_{3} \mathrm{~N}$ contents. Aux el: vitreous carbon, Ref el: Pt.

Pt, visible on each material except tungsten, can be observed. This new wave can be attributed to nitrogen production by oxidation of nitride ions in a one-step process:

$\mathrm{N}^{3-}=1 / 2 \mathrm{~N}_{2(\mathrm{~g})}+3 \mathrm{e}^{-}$

The presence of a disturbance of the electrochemical signal for potentials higher than $1.3 \mathrm{~V}$ vs. Pt, is typical of gas bubbles production, called "bubbles effect", in our case nitrogen. In the particular case of tungsten, a small anodic wave can be observed at around $0.6 \mathrm{~V}$ vs Pt. This wave could be attributed to the formation of a $\mathrm{W}-\mathrm{N}$ compound.

It can be noted that copper oxidation occurs at a potential close to nitride ions oxidation, whereas gold oxidation potential is very far from nitride ions one. Consequently, gold electrode was selected to investigate the electrochemical pathway for nitrogen production.

Fig. 4 presents cyclic voltammograms performed on gold electrode in $\mathrm{LiF}-\mathrm{CaF}_{2}$ melt with various $\mathrm{Li}_{3} \mathrm{~N}$ content at $1113 \mathrm{~K}$ and $100 \mathrm{mV} \mathrm{s}^{-1}$. It can be observed that the peak current density increases when the $\mathrm{N}^{3-}$ concentration in the melt increases at a given temperature. A linear relationship between the peak current density and the $\mathrm{N}^{3-}$ content has been highlighted in Fig. 5 . This result proves that the anodic peak is attributed to the nitride ions oxidation, in agreement with results presented by Ito et al. in molten chlorides [4].

In order to determine the reversibility and limitation of the electrochemical oxidation process, the influence of the potential scan rate on the cyclic voltammograms was studied. Fig. 6 presents the variation of peak potential and peak intensity with the potential scan rate. This figure shows that anodic peak potential is not influenced by potential scan rate, and proves that the electrochemical

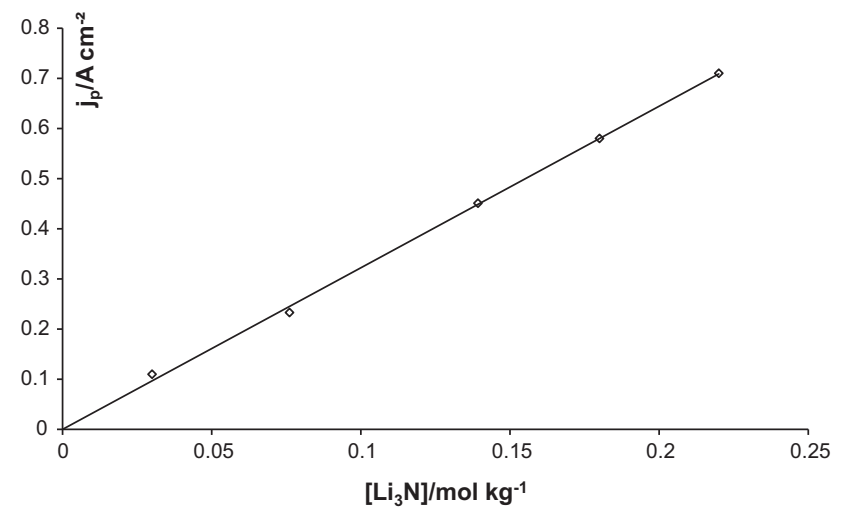

Fig. 5. Linear relationship between the peak current density and the $\mathrm{Li}_{3} \mathrm{~N}$ content on gold electrodeat $1113 \mathrm{~K}$ and $100 \mathrm{mV} \mathrm{s}^{-1}$. Aux el: vitreous carbon, Ref el: Pt.

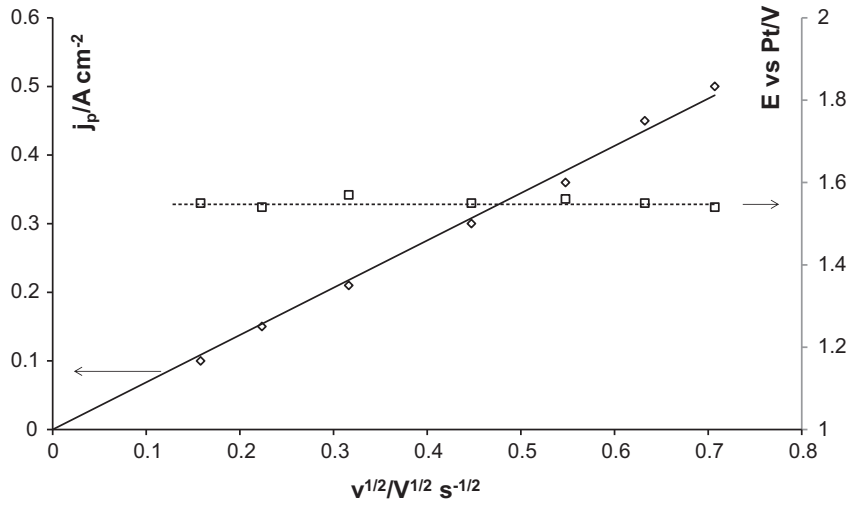

Fig. 6. Variation of the peak current density (left axis) and oxidation peak potential (right axis) versus the square root of the scan rate on gold electrode, for $\left[\mathrm{Li}_{3} \mathrm{~N}\right]=0.105 \mathrm{~mol} \mathrm{~kg}^{-1} . T=1113 \mathrm{~K}$; Aux el: vitreous carbon, Ref el: Pt.

system is reversible. Then, the linearity of $i_{p}$ versus $v^{1 / 2}$, observed in this figure, indicates that the electrochemical oxidation process is controlled by the diffusion of $\mathrm{N}^{3-}$ ions in the solution, as mentioned by the Berzins-Delahay equation [11]:

$I_{p}=0.61 n F S D c^{\circ} \sqrt{\frac{n F D}{R T}} \sqrt{v}$

where $S$ is the electrode area $\left(\mathrm{m}^{2}\right), c^{\circ}$ is the solute concentration $\left(\mathrm{molm}^{-3}\right), D$ is the diffusion coefficient $\left(\mathrm{m}^{2} \mathrm{~s}^{-1}\right), F$ is the Faraday constant $\left(\mathrm{C} \mathrm{mol}^{-1}\right), n$ is the number of exchanged electrons, $T$ is the temperature $(\mathrm{K})$ and $v$ is the potential scanning rate $\left(\mathrm{V} \mathrm{s}^{-1}\right)$.

The slope is equal to $0.689 \mathrm{~A} \mathrm{~cm}^{-2} \mathrm{~s}^{1 / 2} \mathrm{~V}^{-1 / 2}$.

3.2.2. Number of exchanged electrons determination

Using square wave voltammetry, it is possible to determine the number of exchanged electrons by a mathematical analysis of the SWV peak: the half-width of the peak $\left(W_{1 / 2}\right)$ is correlated to the number of exchanged electrons by the following relation [12].

$W_{1 / 2}=3.52 \frac{R T}{n F}$

where $F$ is the Faraday constant $\left(\mathrm{C} \mathrm{mol}^{-1}\right), n$ is the number of exchanged electrons, $T$ is the temperature $(K)$.

Fig. 7 presents a square wave voltammogram carried out on gold electrode at $1113 \mathrm{~K}$ and $100 \mathrm{~Hz}$ for the $\mathrm{LiF}-\mathrm{CaF}_{2}-\mathrm{Li}_{3} \mathrm{~N}$ $\left(0.105 \mathrm{~mol} \mathrm{~kg}^{-1}\right)$ system.

According to cyclic voltammetry, one anodic peak, corresponding to nitride ions oxidation, is observed at a lower potential than gold oxidation.

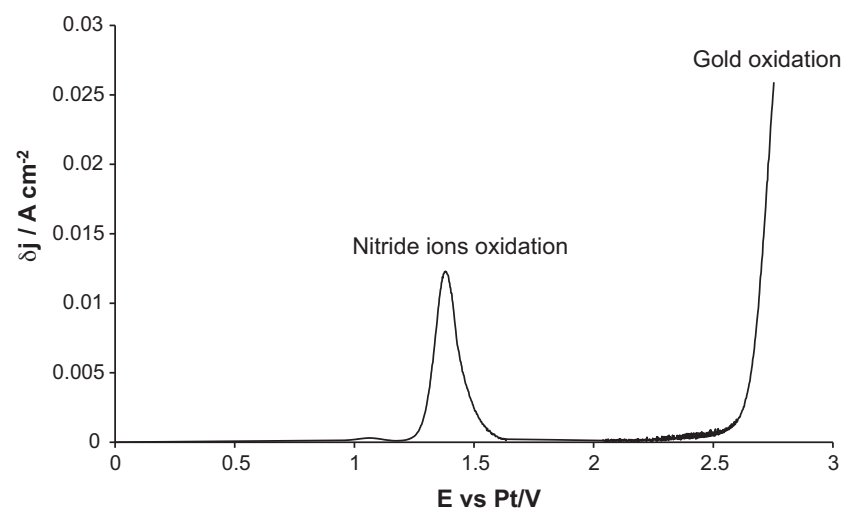

Fig. 7. SWV voltammogram of $\mathrm{LiF}-\mathrm{CaF}_{2}-\mathrm{Li}_{3} \mathrm{~N}$ on Au electrode at $1113 \mathrm{~K}$ and $100 \mathrm{~Hz}$ for $\left[\mathrm{Li}_{3} \mathrm{~N}\right]=0.028 \mathrm{~mol} \mathrm{~kg}^{-1}$. Aux el: vitreous carbon, Ref el: Pt. 


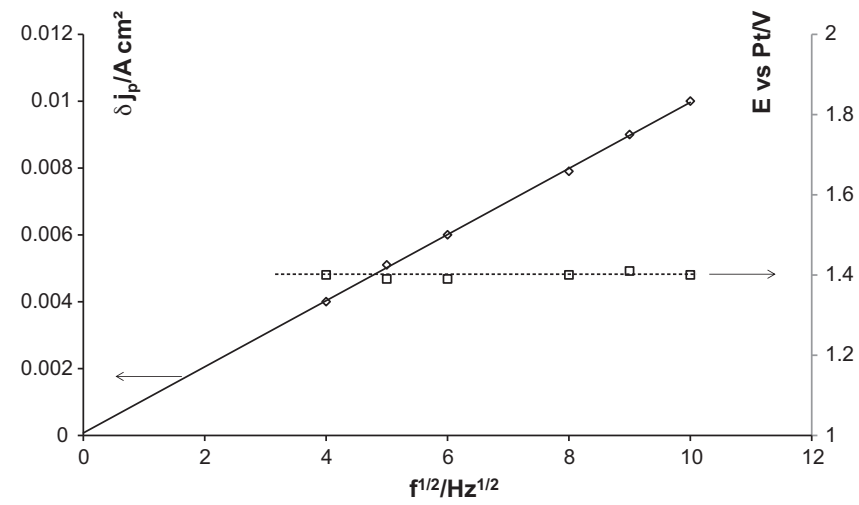

Fig. 8. Variation of the differential peak current density (left axis) and oxidation peak potential (right axis) versus the square root of the frequency on Au electrode for $\left[\mathrm{Li}_{3} \mathrm{~N}\right]=0.028 \mathrm{~mol} \mathrm{~kg}^{-1}$. $T=1113 \mathrm{~K}$; Aux el: vitreous carbon, Ref el: Pt.

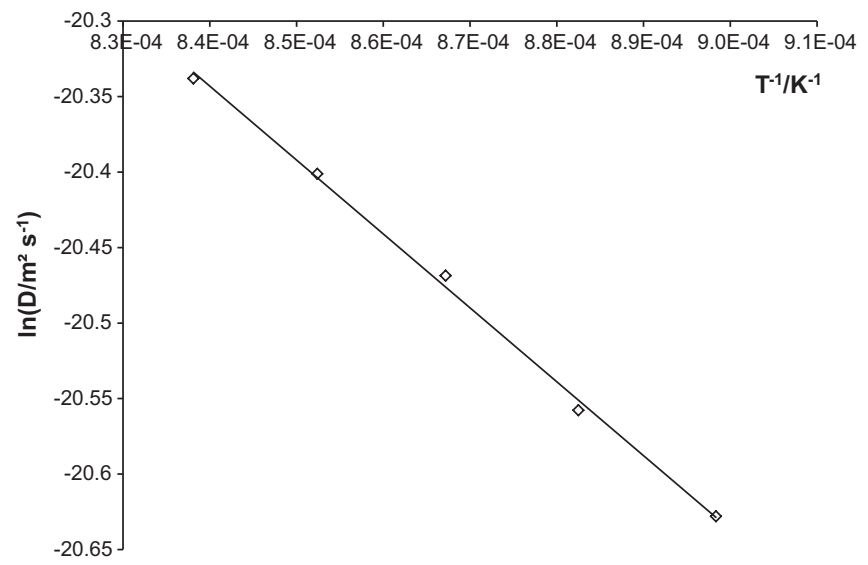

Fig. 9. Linear relationship between the logarithm of diffusion coefficient and the inverse of the absolute temperature.

The validity of application of Eq. (8) was verified by plotting the peak current density and peak potential versus the square root of the frequency as reported in previous work [13]. The invariance of peak potential and the linearity observed in Fig. 8 in the $9-100 \mathrm{~Hz}$ frequency range confirm the reversibility of the electrochemical system and the limitation by the diffusion.

Consequently, using Eq. (8), the average measurement of $W_{1 / 2}$ is $0.109 \pm 0.007 \mathrm{~V}$, leading to a number of exchanged electrons equal to $3.1 \pm 0.2$. This result confirms the validity of reaction (6) for nitrogen production.

\subsubsection{Diffusion coefficient determination}

The diffusion coefficient of $\mathrm{N}^{3-}$ ions can be calculated using Eq. (7). At $1113 \mathrm{~K}$ and $\left[\mathrm{Li}_{3} \mathrm{~N}\right]=0.105 \mathrm{~mol} \mathrm{~kg}^{-1}$, the following average result has been found:

$D_{\mathrm{N}} 3-=(1.10 \pm 0.04) \times 10^{-9} \mathrm{~m}^{2} \mathrm{~s}^{-1}$

This value can be compared to the results of Ito et al. [4] who obtained a similar value of $1.8 \times 10^{-9} \mathrm{~m}^{2} \mathrm{~s}^{-1}$ in molten $\mathrm{LiCl}-\mathrm{KCl}$ at $723 \mathrm{~K}$.
The calculation of $D$ was repeated at several temperatures. The results obey to the following relationship (Arrhenius' law), as verified in Fig. 9:

$\ln D_{\left(\mathrm{m}^{2} \mathrm{~s}^{-1}\right)}=-16.176-\frac{4954.9}{T_{(\mathrm{K})}}$

From this relationship, the value of the activation energy is found to be $41.2 \pm 0.8 \mathrm{~kJ} \mathrm{~mol}^{-1}$.

\section{Conclusions}

The electrochemical behaviour of nitride ions $\mathrm{N}^{3-}$ was studied in the $\mathrm{LiF}-\mathrm{CaF}_{2}$ medium in the $1023-1223 \mathrm{~K}$ temperature range. A thermodynamic analysis can be performed in order to evaluate the anodic material (oxidation potential, reactivity regarding to nitrogen).

Electrochemical investigations results show that on an inert material, as gold, the production of nitrogen gas occur according to the following reaction:

$\mathrm{N}^{3-}=1 / 2 \mathrm{~N}_{2(\mathrm{~g})}+3 \mathrm{e}^{-}$

This reaction is limited by the diffusion of nitride ions in the solution and the diffusion coefficient for several temperatures:

$\ln D_{\left(\mathrm{m}^{2} \mathrm{~s}^{-1}\right)}=-16.176-\frac{4954.9}{T_{(\mathrm{K})}}$

This preliminary study proves that nitrogen evolution is a suitable alternative route for the use as anodic reaction in all electrochemical cathodic processes where chlorine, carbon dioxide or oxygen anodic production could cause corrosion phenomena, or other disturbance, with the material structure of the experimental set up. The perspectives of the study consists on the investigation of electrochemical behaviour of nitride ions on reactive anode material (reactive oxidation) in order to produce metal nitrides layers, which have interesting properties for surface treatment.

\section{Acknowledgment}

This work was supported by the European ACSEPT (FP7-CP2007-211 267) program.

\section{References}

[1] D.R. Sadoway, JOM-J. Min. Met. Mater. 53 (2001) 34

[2] L. Massot, L. Cassayre, P. Chamelot, P. Taxil, J. Electroanal. Chem. 606 (2007) 17.

[3] H. Takano, H. Akie, T. Osugi, T. Ogawa, Prog. Nucl. Energy 32 (1998) 373

[4] Y. Ito, T. Goto, J. Nucl. Mater. 344 (2005) 128.

[5] T. Goto, T. Iwaki, U. Ito, Electrochim. Acta 50 (2005) 1283.

[6] T. Goto, H. Ishigaki, Y. Ito, Mater. Sci. Eng. 371 (2004) 353.

[7] T. Goto, Y. Ito, J. Phys. Chem. Solids 66 (2005) 418

[8] H. Tsujimura, T. Goto, Y. Ito, J. Alloys Compd. 376 (2004) 246.

[9] L. Massot, P. Chamelot, P. Taxil, Electrochim. Acta 50 (2005) 5510.

[10] A.D. Graves, D. Inman, Nature 208 (1965) 481.

[11] T. Berzins, P. Delahaye, J. Am. Chem. Soc. 75 (1953) 555

[12] L. Ramalay, M.S. Kraus, Anal. Chem. 41 (1969) 1362.

[13] P. Chamelot, B. Lafage, P. Taxil, Electrochim. Acta 43 (1997) 607. 